\title{
INDICADORES DE INTERATIVIDADE PARA O PROFESSOR PRESENCIAL E ON-LINE ${ }^{1}$
}

\section{Interactive indicators to the classroom and on-line teacher}

Resumo

A docência interativa presencial e on-line é demanda da cibercultura, isto é, do novo ambiente comunicacional que surge com a interconexão mundial de computadores em forte expansão no início do século 21; novo espaço de comunicação, de sociabilidade, de organização, de informação, de conhecimento e de educação. O professor acostumado ao primado da transmissão na educação e na mídia de massa tem agora o desafio de educarna cibercultura. Terá que desenvolversuaimaginação criadora para atenderas novas demandas sociais de aprendizagem interativa. Interatividade é a modalidade comunicacional que ganha centralidade na "cibercultura". Exprime a disponibilização consciente de um mais comunicacional expressamente complexo presente na mensagem e previsto pelo emissor, que abre ao receptor a possibilidade de responder ao sistema de expressão e de dialogar com ele. Grande salto qualitativo em relação ao modo de comunicação de massa que prevaleceu até o final do século XX, o modo de comunicação interativa ameaça a lógica unívoca da mídia de massa, oxalá como superação do constrangimento da recepção passiva. Este texto reúne diversas sugestões sistematizadas como "indicadores de interatividade" capazes de redimensionar a prática docente presencial e on-line. Com esses indicadores, o professor poderá rever sua autoria na construção da aprendizagem, transformando o ambiente de comunicação, tomando possível a transição de um modelo centrado na seqüência linear, que encadeia unidirecionalmente graus, idades e pacotes de conhecimento, a outro descentrado e plural, cuja chave é o encontro do texto e o hipertexto. Para tanto, o professor precisará se dar conta do movimento próprio das tecnologias digitais em sintonia com a cibercultura e com o perfil comunicacional dos aprendizes que aprenderam com o controle remoto e com a lógica unívoca da mídia de massa e agora aprendem com o mouse e com as "janelas" móveis que permitem mais do que meramente assistir.

Palavras-chave: Docência; Cibercultura; Interatividade; Sala de aula presencial; Educação on-line.

1 Este texto é uma versão ampliada do texto "Docência interativa presencial e on-line" publicado no CD-ROM da V ANPED SUL, Seminánio de Pesquisa em Educação da Região Sul, Curitiba, PR, 2004.

2 Sociólogo (UFRJ), Doutor em Educação (USP), professor do Programa de Pós-Graduação em Educação da Estácio e da Faculdade de Educação da UERJ. Av. Princesa Isabel, 334/Bl.3/806 22011-010 - Copacabana, Rio de Janeiro, RJ. Autor do livro Sala de aula interativa, 3. ed. Quartet 2003. Site: www.saladeaulainterativa.pro.br - E-mail: marco@msm.com.br 


\section{Abstract}

The classroom and on-line interactive teaching is a demand of the cyber culture, that is, of the new communicational environment that appears with strongly expanding at the early XXI Century worldly computers interconnection; a communication, sociability, organization, information, knowledge and education new space. In permanent contact with the transmission primacy over education and mass media, the teacher now faces a challenge: educating at the cyber culture. He will need to develop his creative imagination to answer the new social demands for interactive learning. Interactivity is the communicational mode that outstands at the so called "cyber culture". It manifests an understandable availability in a clear complex way of a communication plus present at the message and foresaw by the emitter that makes the receiver able to answer the expression system and to dialogue with it. Great quality jumps in comparison with the mass communication mode that has predominated until the end of XX Century, the interactive communication mode menaces the mass media univocal logic, let's hope outmoding the passive receiving constraint. This paper brings together several suggestions systemized as "interactivity indicator" and permits to re-measuring both the classroom and on-line teaching practice. By handling these indicators, the teacher will be able to re-examine his authorship at the learning construction, converting the communication environment, making possible the transition from a model centered in a linear sequence that enchains unidirectional levels, ages and knowledge packs, to another uncentered and plural, of which key is the text/hypertext meeting. To accomplish this, the teacher will need to become aware of the digital technologies own movement, be in tune with the cyber culture, with the communication profile of the learners, who learned with the remote control and with the mass media univocal logic, and now are learning with the mouse and with the mobile windows that allows more than merely watch.

Keywords: Teaching; Cyberculture; Interactivity; Classroom; On-line education

\section{Introdução}

Nós professores tivemos diversos mestres em educação questionando nossa prática docente baseada na "pedagogia da transmissão". Doravante teremos, além desses valorosos mestres, o desafio da cibercultura. Cito, por exemplo, dois dos maiores gênios brasileiros que souberam nos provocar tão intensamente: Anísio Teixeira e Paulo Freire.

Num primoroso texto avançado em seu tempo, Anísio ${ }^{1}$ deixa claro que o professor deveria lançar mão dos "novos recursos tecnológicos e dos meios audiovisuais" não para transmitir conteúdos, ao contrário, buscaria neles rompimento com a pedagogia da transmissão. Ou seja, rádio, cinema e 
televisão "irão transformar o mestre no estimulador e assessor do estudante". De "guardião e transmissor da cultura", o mestre seria transformado, graças à parceria com as tecnologias de comunicação, em "guia de aprendizagem" e em "orientador em meio às dificuldades da aquisição das estruturas e modos de pensar fundamentais da cultura contemporânea". Em lugar de transmitir pacotes de informações em sala de aula, o mestre, a par da dinâmica do conhecimento em permanente expansão, poderia "ensinar ao jovem aprendiz a aprender os métodos de pensar das ciências físico-matemáticas, biológicas e sociais, a fim de habilitá-lo a fazer de toda a sua vida uma vida de instrução e de estudos". Em suma: com as tecnologias de comunicação, mestres e estudantes estariam mais empenhados em "descobrir, em aumentar o saber, do que no próprio saber existente propriamente dito"(TEIXEIRA, 1003-On-line).

Sem evidenciar em princípio o auxílio das tecnologias educacionais, Paulo Freire é também enfático quanto à necessidade de salto de qualidade, quando inúmeras vezes insiste em criticar a transmissão como modelo mais identificado como prática de ensino e menos habilitado a educar:

O professor ainda é um ser superior que ensina a ignorantes. Isto forma uma consciência bancária [sedentária, passiva]. O educando recebe passivamente os conhecimentos, tomando-se um depósito do educador. Educa-se para arquivar o que se deposita. [...]A consciência bancária 'pensa que quanto mais se dá mais se sabe. (FREIRE, 1979, p. 38).

Dizendo assim, ele critica o ensino que não estimula a expressão criativa e transforma o estudante no receptor passivo que perdeu a capacidade de ousar.

Quem apenas fala e jamais ouve; quem 'imobiliza' o conhecimento e 0 transfere a estudantes, não importa se de escolas primárias ou universitárias; quem ouve o eco apenas de suas próprias palavras, numa espécie de narcisismo oral [...], não tem realmente nada que ver com libertação nem democracia. (FREIRE, 1982, 30-31).

Portanto, "ensinar não é a simples transmissão do conhecimento em torno do objeto ou do conteúdo. Transmissão que se faz muito mais através da pura descrição do conceito do objeto a ser mecanicamente memorizado pelos alunos".(FREIRE, 1992, p. 81).

Hoje, após décadas de importância amplamente reconhecida, podemos verificar que o empenho dos grandes mestres gerou pouca modificação em nossa prática pedagógica. Continuamos guardiões e transmissores da cultura, transmissores de pacotes fechados de informações em sala de aula presencial e a distância. Educamos para arquivar o que depositamos nas mentes 
dos nossos alunos. Assim, cristalizando a consciência bancária que pensa que quanto mais se distribui, mais se apropria do conhecimento.

Mesmo havendo uma percepção crescente de que o professor precisa investir em relações de reciprocidade para construir conhecimento, poucas modificações efetivas podem ser aferidas em nossa prática docente. A "escola democrática" de Anísio e a "pedagogia do oprimido" de Freire ganharam enorme adesão destacando o papel central da participação e da dialógica como fundamento da aprendizagem. Suas diversas interpretações vêm mostrando que a aprendizagem é um processo de atuação crítica do discente que elabora os saberes graças e por meio das interações com outrem. No entanto, falta aos sensibilizados por essas vertentes pedagógicas um tratamento adequado da comunicação de modo que se permita efetivar as interações e a aprendizagem em lugar da transmissão e da memorização.

Quero dizer que, mesmo adeptos das orientações desses mestres, os professores podem permanecer apegados ao modelo da transmissão que faz repetir e não construir. Isto porque não desenvolveram uma atitude comunicacional que favoreça promover as participações e dialógica como condição sine qua non da aprendizagem. Falo de uma atitude comunicacional que não apenas atente idealmente para a participação e para a dialógica, mas que também as promova concretamente no cotidiano da sala de aula presencial e a distância. Essa atitude supõe técnicas específicas, mas antes de tudo requer a percepção crítica de uma mudança paradigmática em curso na cibercultura.

A seguir, reúno aspectos que considero essenciais no tratamento de uma pedagogia baseada na interatividade. Uma pedagogia que rompe com a prevalência da pedagogia da transmissão, disponibilizando aos alunos a participação na construção do conhecimento e da própria comunicação entendida como colaboração da emissão e da recepção, e assim, sintonizada com 0 nosso tempo. Os referidos aspectos serão situados no decorrer do texto e, no seu final, sistematizados como "indicadores de interatividades" ou como sugestões ao professor presencial e on-line.

\section{Cibercultura e o novo paradigma comunicacional}

Cibercultura é o "conjunto de técnicas materiais e intelectuais, de práticas, de atitudes, de modos de pensamento e de valores, que se desenvolvem juntamente com o crescimento do ciberespaço". Ciberespaço é o "novo meio de comunicação que surge com a interconexão mundial de computadores"; é "o principal canal de comunicação e suporte de memória da humanidade a partir do início do século 21"; "espaço de comunicação aberto pela interconexão mundial dos computadores e das memórias dos computadores"; "novo 
espaço de comunicação, de sociabilidade, de organização e de transação, mas também o novo mercado da informação e do conhecimento" que "tende a tornar-se a principal infra-estrutura de produção, transação e gerenciamento econômicos". (LEVY, 1999, p. 32; 92; 167).

Podemos dizer que ciberespaço significa rompimento paradigmático com o reinado da mídia de massa baseada na transmissão. Enquanto esta efetua a distribuição para o receptor massificado, o ciberespaço, fundado na codificação digital permite ao indivíduo teleintrainterante a comunicação personalizada, operativa e colaborativa em rede hipertextual.

Em termos práticos pode-se dizer: o site não deve ser assistido como se faz diante da tela da TV e sim manipulado, operado, pois a tela do computador conectado pressupõe imersão e participação-intervenção do indivíduo experiência incomum na mídia de massa. O professor atento poderá verificar que os sites ainda são em geral para se ver e saquear e não para interagir. Poderá concluir então que os especialistas em produção de websites estão subutilizando o digital. É como se os webdesigners ou criadores de sites tivessem inveja da televisão, disponibilizando conteúdos on-line somente para que os internautas vejam e façam download. Isso denuncia a força da tradição da transmissão não somente em educação e na mídia de massa. Assim, professores e webdesigners poderão perceber que interagir é mais que assistir. Ou seja, se o aprendiz ou usuário produz, usa e controla, ele ganha, já se ele se tornar um usuário pacífico, que apenas fica sentado em frente à tela ou em frente ao professor, ao quadro negro, ele perde, torna-se tudo entediante.

Essa modalidade comunicacional que emerge com a cibercultura é a interatividade. Não se trata meramente de um novo modismo. O termo significa a comunicação que se faz entre emissão e recepção entendida como cocriação da mensagem. Há críticos que vêem mera aplicação oportunista de um termo "da moda" para significar velhas coisas como diálogo e reciprocidade. Há outros acreditando que interatividade tem a ver com ideologia publicitária, estratégia de marketing, fabricação de adesão, produção de opinião pública. E há também aqueles que dizem jamais se iludir com a interatividade entre homem-computador, pois acreditam que, por trás de uma aparente inocência da tecnologia amigável, "soft", progride a dominação das linguagens infotécnicas sobre o homem. Sem dúvida, aqui estão críticas pertinentes. No entanto, há muito mais a dizer sobre esse conceito emergente. Particularmente, sobre sua importância em educação.

Há certamente uma banalização do termo interatividade. Cito a propaganda de uma marca de tênis na TV em que o produto é apresentado como "interactive". Ou seja, há uma crescente utilização do adjetivo "interativo" para qualificar qualquer coisa (computador e derivados, brinquedos eletrônicos, vestuário, eletrodomésticos, sistema bancário on-line, shows, teatro, estratégi- 
as de propaganda e marketing, programas de rádio e TV, etc.), cujo funcionamento permita ao usuário-consumidor-espectador-receptor algum nível de participação, de troca de ações e de controle sobre acontecimentos. Podemos dizer que há uma indústria da interatividade em franco progresso acenando para um futuro interativo. Caminhamos na direção da geladeira e do microondas interativos. Isso pode significar mais banalização do termo "interatividade", tomado como "excelente argumento de venda", como "promessa de diálogo enriquecedor que faz engolir a pílula". (SFEZ, 1994, p. 267).

A despeito dessa banalização, pode-se verificar a emergência histórica da interatividade como novo paradigma em comunicação. A transmissão, emissão separada da recepção, perde sua força na era digital, na cibercultura, na sociedade da informação, quando está em emergência a imbricação de pelo menos três fatores:

- Tecnológico. Novas tecnologias informáticas conversacionais, isto é, a tela do computador não é espaço de irradiação, mas de adentramento e manipulação, com janelas móveis e abertas a múltiplas conexões. Os informatas encontraram uma nova palavra para exprimir a novidade do computador que substitui as herméticas linguagens alfanuméricas pelos ícones e janelas tridimensionais que permitem interferências e modificações na tela.

- Mercadológico. Estratégias dialógicas de oferta e consumo envolvendo cliente-produto-produtor são valorizadas pelos especialistas em propaganda e marketing.

- Social. Há um novo espectador, menos passivo diante da mensagem mais aberta à sua intervenção, que aprendeu com o controle remoto da TV, com o joystick do videogame e agora aprende como o mouse.

Pode-se dizer que um novo cenário comunicacional ganha centralidade. Ocorre a transição da lógica da distribuição (transmissão) para a lógica da comunicação (interatividade). Isso significa modificação radical no esquema clássico da informação baseado na ligação unilateral emissor-mensagemreceptor.

- O emissor não emite mais no sentido que se entende habitualmente, uma mensagem fechada, oferece um leque de elementos e possibilidades à manipulação do receptor.

- A mensagem não é mais "emitida", não é mais um mundo fechado, paralisado, imutável, intocável, sagrado, é um mundo aberto, modificável na medida em que responde às solicitações daquele que a consulta.

- O receptor não está mais em posição de recepção clássica, é convidado à livre criação, e a mensagem ganha sentido sob sua intervenção. (MARCHAND, 1987, p. 9). 
Trata-se, portanto, de mudança paradigmática na teoria e pragmática comunicacionais. A mensagem só to ma todo o seu significado sob a intervenção do receptor que se torna, de certa maneira, criador. Enfim, a mensagem que agora pode ser recomposta, reorganizada, modificada em permanência sob o impacto das intervenções do receptor dos ditames do sistema, perde seu estatuto de mensagem emitida. Assim, parece claramente que o esquema clássico da informação, que se baseava numa ligação unilateral ou unidirecional emissor-mensagem-receptor, acha-se mal colocado em situação de interatividade. Não a interatividade tomada como "argumento de venda", mas no sentido complexo do termo que supõe pelo menos três princípios.

- O emissor pressupõe a participação-intervenção do receptor: participar é muito mais que responder "sim" ou "não", é muito mais que escolher uma opção dada; participar é modificar, é interferir na mensagem.

- Comunicar pressupõe recursão da emissão e recepção: a comunicação é produção conjunta da emissão e da recepção; o emissor é receptor em potencial e o receptor e emissor em potencial; os dois pólos codificam e decodificam.

- O emissor disponibiliza a possibilidade de múltiplas redes articulatórias: não propõe uma mensagem fechada, ao contrário, oferece informações em redes de conexões permitindo ao receptor ampla liberdade de associações e de significações.

Diante da emergência da interatividade é visível a inquietação de empresários e programadores da mídia clássica, inquietação que ainda não chegou ao campo da educação. É preciso despertar o interesse dos professores para uma nova comunicação com os alunos em sala de aula presencial e virtual. É preciso enfrentar o fato de que tanto a mídia de massa quanto a sala de aula estão diante do esgotamento do mesmo modelo comunicacional que separa emissão e recepção.

Portanto, aprender com o movimento da mídia digital supõe antes de tudo aprender com a interatividade. Ou seja, aprender que comunicar não é simplesmente transmitir, mas disponibilizar múltiplas disposições à intervenção do interlocutor, uma vez que a comunicação só se realiza mediante sua participação.

\section{Sugestões para a docência interativa}

A comunicação interativa é, portanto, o que enfatizo como desafio para a educação centrada no paradigma da transmissão. Trata-se de um desafio que na verdade se desdobra em três. Ao mesmo tempo, o professor 
precisa se dar conta do hipertexto ${ }^{3}$, precisa fazê-lo potenciar sua ação pedagógica sem perder sua autoria; e finalmente precisa perceber ainda que "não se trata de invalidar o paradigma clássico". Martín-Barbero (1998) formula com precisão os termos dessa tripla dimensão do desafio.

- O professor terá que se dar conta do hipertexto: “Uma escritura não seqüencial, uma montagem de conexões em rede que, ao permitir/exigir uma multiplicidade de recorrências, transforma a leitura em escritura".

- O professor precisará saber que "em lugar de substituir, o hipertexto vem potenciar" sua figura e seu ofício: "De mero transmissor de saberes [o professor] deverá converter-se em formulador de problemas, provocador de interrogações, coordenador de equipes de trabalho, sistematizador de experiências e memória viva de uma educação que, em lugar de aferrar-se ao passado [transmissãol, valoriza e possibilita o diálogo entre culturas e gerações".

Para o professor que se dispõe a aprender com o movimento contemporâneo da tecnologia hipertextual, pode-se mostrar a distinção entre mídia clássica e mídia digital ou hipertextual. Este professor poderá se dar conta de que tal modificação significa a emergência de um novo leitor. Não mais aquele que segue as páginas do livro de modo unitário e contínuo, mas aquele que salta de um ponto a outro fazendo seu próprio roteiro de leitura. Não mais o que se submete às récitas da emissão, mas o que, não se identificando apenas como receptor, interfere, manipula, modifica e, assim, reinventa mensagem.

O professor pode perceber nesta distinção que ter a experiência de intervenção na mensagem difere da recepção passiva de informações. E ao se dar conta disso, ele pode redimensionar sua sala de aula, modificar sua base comunicacional, inspirando-se no digital. Ele modifica o modelo centrado no seu falar-ditar e passa a disponibilizar ao aluno autoria, participação, manipulação, co-autoria e informações as mais variadas possíveis, facilitando permutas, associações, formulações e modificações na mensagem.

3 "O que é um hipertexto? Em termos bastante simplificados, podemos explicá-lo da seguinte maneira: todo texto, desde a invenção da escrita, foi pensado e praticado como um dispositivo linear, como sucessão retilínea de caracteres, apoiada num suporte plano. A idéia básica do hipertexto é aproveitar a arquitetura não-linear das memórias de computador para viabilizar textos tridimensionais como aqueles do holopoema, porém dotados de uma estrutura dinâmica que os torne manipuláveis interativamente. (...) A maneira mais usual de visualizar essa escritura múltipla na tela plana do monitor de vídeo é por meio de 'janelas' (windows) paralelas, que se pode ir abrindo sempre que necessário, e também por meio de 'elos' (links) que ligam determinadas palavras-chave de um texto a outros disponíveis na memória". 
O termo disponibilizar, propriamente utilizado pelos designers de website, não se reduz ao permitir, pois nas tecnologias digitais não tem sentido apenas permitir sem dispor (arrumar de certo modo, promover, ensejar, predispor, urdir, arquitetar teias). Disponibilizar em sua sala de aula significará basicamente três aspectos.

- Oferecer múltiplas informações (em imagens, sons, textos, etc.) utilizando ou não tecnologias digitais, mas sabendo que estas, utilizadas de modo interativo, potencializam consideravelmente ações que resultam em conhecimento.

- Ensejar (oferecer ocasião de...) e urdir (dispor entrelaçados os fios da teia, enredar) múltiplos percursos para conexões e expressões com o que os alunos possam contar no ato de manipular as informações e percorrer percursos arquitetados.

- Estimular cada aluno a contribuir com novas informações e a criar e oferecer mais e melhores percursos, participando como co-autor do processo.

O professor, neste caso, constrói uma rede e não uma rota. Ele define um conjunto de territórios a explorar. E a aprendizagem se dá na exploração - ter a experiência - realizada pelos alunos e não a partir da sua récita, do seu falar-ditar. Isto significa modificação em seu clássico posicionamento na sala de aula. Significa antes de tudo que ele não mais se posiciona como o detentor do monopólio do saber, mas como o que disponibiliza a experiência do conhecimento. Ele predispõe teias, cria possibilidades de envolvimento, oferece ocasião de engendramentos, de agenciamentos. E estimula a intervenção dos alunos como co-autores de suas ações.

Assim, o professor modifica sua ação, alterando seu modo de comunicar em sala de aula. Na perspectiva da interatividade, deixa de ser o locutor que imobiliza o conhecimento e o transfere aos alunos em sua récita. Mas não para se tornar apenas um conselheiro, uma ponte entre a informação e o conhecimento. Tampouco para ser apenas um "parceiro, um pedagogo no sentido clássico do termo, que encaminhe e oriente 0 aluno diante das múltiplas possibilidades de alcançar o conhecimento e se relacionar com ele". E muito menos como "facilitador". Os termos "conselheiro", "parceiro" e "facilitador" são óbvios e simplificam. Mais vale então a formulação de MartínBarbero (1989, p. 23) "sistematizador de experiências", que tem a ver com ensejar (oferecer ocasião de) e urdir (dispor os fios da teia, tecer junto).

A expressão "sistematizador de experiências", no sentido do hipertexto, significaria então disponibilizar possibilidades de múltiplas experimentações e de múltiplas expressões. Isto é precisamente o que faz o designer 
de software: uma montagem de conexões em rede que permite múltiplas recorrências. Assim também o professor que modifica sua prática comunicacional no sentido do hipertexto. Ele é um "sistematizador de experiências". De mero transmissor de saberes, "parceiro" ou "conselheiro", ele torna-se um formulador de problemas, provocador de situações, arquiteto de percursos, enfim, agenciador da construção do conhecimento na experiência viva da sala de aula.

Tudo isso pode ser engendrado na sala de aula on-line.

$\mathrm{O}$ ambiente virtual de aprendizagem deve favorecer a interatividade entendida como participação colaborativa, bidirecionalidade e dialógica, e conexão de teias abertas como elos que traçam a trama das relações. $\mathrm{O}$ informata que programa esse ambiente conta de início com o fundamento digital, mas para garantir hipertexto e interatividade terá que ser capaz de construir interfaces favoráveis à criação de conexões, interferências, agregações, multiplicidade, usabilidade e integração de várias linguagens (sons, textos, fotografia, vídeo). Terá que garantir a possibilidade de produção conjunta do professor e dos alunos e aí a liberdade de trocas, associações e significações como autoria e co-autoria (SILVA, 2000, p. 62).

O professor precisará observar que:

o site ou AVA [ambiente virtual de aprendizagem] precisa ser uma obra aberta, onde a imersão, navegação, exploração e a conversação possam fluir na lógica da completação. Isso significa que o AVA deve agregar a criação no devir, todos os participantes poderão contribuir no seu design e na sua dinâmica curricular. (SANTOS apud SILVA, 2003, p. 225).

Ele terá, portanto, que atentar para cuidados essenciais.

- Criar sites hipertextuais que agreguem intertextualidade, conexões com outros sites ou documentos; intratextualidade, conexões no mesmo documento; multivocalidade, agregar multiplicidade de pontos de vistas; navegabilidade, ambiente simples e de fácil acesso e transparência nas informações; mixagem, integração de várias linguagens: sons, texto, imagens dinâmicas e estáticas, gráficos, mapas; multimídia integração de vários suportes midiáticos.

- Potencializar comunicação interativa síncrona, comunicação em tempo real e assíncrona, comunicação a qualquer tempo - emissor e receptor não precisão estar no mesmo tempo comunicativo.

- Criar atividades de pesquisa que estimule a construção do conhe- 
cimento a partir de situações problemas, onde o sujeito possa contextualizar questões locais e globais do seu universo cultural.

- Criar ambiências para avaliação formativa, onde os saberes sejam construídos num processo comunicativo de negociações em que a tomada de decisões seja uma prática constante para a (re)significação processual das autorias e co-autorias.

- Disponibilizar e incentivar conexões lúdicas, artísticas e navegações fluidas (SANTOS apud SILVA, 2003, p. 225).

O professor seria então aquele que oferece possibilidades de aprendizagem, disponibilizando conexões para recorrências e experimentações que ele tece com os alunos. Ele mobiliza articulações entre os diversos campos de conhecimento tomados como rede ${ }^{4}$ inter/transdiciplinar e, ao mesmo tempo, estimula a participação criativa dos alunos, considerando suas disposições sensoriais, motoras, afetivas, cognitivas, culturais e intuitivas.

Em suma, as diversas sugestões para uma docência interativa citadas até aqui podem ser sistematizadas como "indicadores de interatividade" em educação presencial e on-line. São pelo menos cinco linhas que interligam engajamentos do professor capazes de promover a superação da prevalência da pedagogia da transmissão.

\section{Disponibilizar múltiplas experimentações, múltiplas expres- sões.}

- Promover oportunidades de trabalho em grupos colaborativos.

- Desenvolver o cenário das atividades de aprendizagem de modo a possibilitar a participação livre, o diálogo, a troca e a articulação de experiências.

- Utilizar recursos cênicos para despertar e manter o interesse e a motivação do grupo envolvido.

- Favorecer a participação coletiva em debates presenciais e on-line.

4 Faço referência à concepção de currículo escolar ou de conteúdos programáticos como "rede". Ou seja, não se trata de lidar com os conteúdos curriculares entendidos como unidades apresentadas em seqüência linear, hierárquica, encadeando pacotes de conhecimento, mas como campos ou dimensões do saber que podem estabelecer múltiplas conexões entre si. Sobre tal abordagem inspirada no hipertexto.

5 Esses "indicadores de interatividade" foram sistematizados a partir do livro Sala de aula interativa (ver referência) pelo grupo de pesquisa que coordeno na linha de pesquisa Tecnologias da Informação e da Comunicação nos Processos Educacionais do Programa de Pós-Graduação em Educação da Universidade Estácio de Sá. Com esses indicadores, estamos pesquisando a ambiência comunicacional em três salas de aula: uma desprovida de computadores, outra em laboratório de informática e uma terceira em curso on-line. 
- Garantir a exposição de argumentos e o questionamento das afirmações.

\section{Disponibilizar uma montagem de conexões em rede que permite múltiplas ocorrências.}

- Fazer uso de diferentes suportes e linguagens midiáticos (texto, som, vídeo, computador, Internet) em mixagens e em multimídia, presenciais e on-line.

- Garantir um território de expressão e aprendizagem labiríntico com sinalizações que ajudam o aprendiz a não se perder, mas que ao mesmo tempo não o impeça de perder-se.

- Desenvolver, com a colaboração de profissionais específicos, um ambiente intuitivo, funcional, de fácil navegação e que poderá ser aperfeiçoado na medida da atuação dos aprendizes.

- Propor a aprendizagem e o conhecimento como espaços abertos à navegação, colaboração e criação, possibilitar que o aprendiz conduza suas explorações.

\section{Provocar situações de inquietação criadora}

- Promover ocasiões que despertem a coragem do enfrentamento em público diante de situações que provoquem reações individuais e grupais.

- Encorajar esforços no sentido da troca entre todos os envolvidos, juntamente com a definição conjunta de atitudes de respeito à diversidade e à solidariedade.

- Incentivar a participação dos estudantes na resolução de problemas apresentados, de forma autônoma e cooperativa.

- Elaborar problemas que convoquem os estudantes a apresentar, defender e, se necessário, reformular seus pontos de vista constantemente.

- Formular problemas voltados para o desenvolvimento de competências que possibilitem ao aprendiz ressignificar idéias, conceitos e procedimentos.

\section{Arquitetar percursos hipertextuais}

- Articular o percurso da aprendizagem em caminhos diferentes, multidisciplinares e transdisciplinares, em teias, em vários atalhos, reconectáveis a qualquer instante por mecanismos de associação.

- Explorar as vantagens do hipertexto: disponibilizar os dados de conhecimento exuberantemente conectados e em múltiplas cama- 
das ligadas a pontos facilitam o acesso e o cruzamento de informações e de participações.

- Implementar no roteiro do curso diferentes desenhos e múltiplas combinações de linguagens e recursos educacionais retirados do universo cultural do estudante e atento aos seus eixos de interesse.

\section{Mobilizar a experiência do conhecimento}

- Passarelli (1993) observa que:

Modelar os domínios do conhecimento como espaços conceituais, onde os alunos podem construir seus próprios mapas e conduzir suas explorações, considerando os conteúdos como ponto de partida e não como ponto de chegada no processo de construção do conhecimento (p. 66).

- Desenvolver atividades que propiciem não só a livre expressão, 0 confronto de idéias e a colaboração entre os estudantes, mas, que permitam também, o aguçamento da observação e da interpretação das atitudes dos atores envolvidos.

- Implementar situações de aprendizagem que considerem as experiências, conhecimentos e expectativas que os estudantes já trazem consigo.

Estas cinco linhas de sugestões podem potencializar a autoria do professor, presencial e à distância, com agenciamentos de comunicação capazes de atender o perfil do novo espectador que emerge com a cibercultura. $\mathrm{O}$ professor pode promover uma modificação qualitativa da pragmática comunicacional fundada na transmissão e modificar a prática docente baseada no falar-ditar do mestre.

Refiro-me à possibilidade de modificação da tradicional sala de aula presencial baseada no baixo nível de participação oral dos alunos, na ênfase em atividades solitárias, na aprendizagem mecânica de conhecimento factual como principal objetivo do ensino, enfim, na distribuição em massa do "conhecimento".

Refiro-me também à sala de aula "à distância" - seja com base em tecnologia analógica (rádio e TV), seja em tecnologia digital (Internet) -, comodamente baseada na manutenção de barreiras intransponíveis entre a produção e a recepção da comunicação e do conhecimento.

A utilização da TV como veículo de "ensino à distância" tem revelado que o perfil comunicacional da "telessala" ou da "teleaula" se mantém em grande parte de acordo com a lógica da distribuição, isto é, como transmissão, como difusão de informações. E, com a utilização da Internet, vem a utilização 
da tecnologia hipertextual interativa, reavivando e ampliando o interesse pela aprendizagem à distância e redimensionando o próprio conceito de sala de aula e de educação. A Internet traz o conceito de sala de aula "virtual" ou "ciberespacial". Trata-se do ambiente de aprendizagem e de socialização gerado na interconexão dos computadores em rede. Cada aluno, a partir de qualquer lugar, utiliza seu computador conectado à Internet para acessar o site do curso. Ali ele encontra o material pedagógico que o convida e estimula a realizar pesquisas, desenvolver projetos, em rede com os outros alunos e com o professor. O professor disponibiliza informações, propostas de trabalho, links para sites temáticos, bibliografia, imagens, músicas, filmes, além do planejamento do curso especificando objetivos e conteúdos programáticos. Com a tecnologia digital ele pode promover certos agenciamentos de comunicação como: incentivar a troca de experiências, a ajuda mútua, a participação em debates on-line e a construção coletiva do conhecimento e da própria comunicação. O professor torna-se animador da participação e da colaboração. Sua principal função não pode mais ser uma difusão de conhecimentos, que agora é feita de forma mais eficaz por outros meios. A Internet abre essa perspectiva. Entretanto, é preciso cuidar para que a tecnologia digital não seja subutilizada ou para que haja de fato interatividade.

Portanto, é preciso enfatizar a necessidade de modificar a modalidade comunicacional predominante na ação pedagógica do professor a partir do movimento contemporâneo das tecnologias hipertextuais, esclarecendo que isso não significa meramente uma nova tecnificação da sala de aula. Em primeiro lugar está a função social da escola, que não é simplesmente a socialização das novas gerações no contexto das novas tecnologias - a "alfabetização digital" entendida num sentido restrito: gerar mão-de-obra para o mercado de trabalho cada vez mais informatizado -, mas, acima de tudo, a educação do sujeito em nosso tempo.

\section{Considerações finais}

Em sala de aula, a docência interativa ocorre mediante participação, bidirecionalidade, multiplicidade de conexões e simulações/experimentação. Mesmo que não haja tecnologias digitais, é possível engendrar essa docência. Pode-se, por exemplo, investir em multiplicidade de nós e conexões - no sentido mesmo do hipertexto - utilizando textos, fragmentos da programação da TV, filmes inteiros ou em fragmentos, gravuras, jornais, música, falas, performances, etc. Nesse ambiente, o professor disponibiliza roteiros em rede e oferece ocasião de exploração, de permutas e potencializações (dos temas e dos suportes). Aí ele estimula a co-autoria e a fala livre e plural. 
Se não há computador e Internet, bastará um fragmento em vídeo para detonar uma intrincada rede de múltiplas conexões com alunos e professor, interagindo e construindo conhecimento.

Ou seja: a sala de aula infopobre pode ser rica em interatividade, uma vez que o que está em questão é o movimento contemporâneo das tecnologias e não necessariamente a presença da infotecnologia. Claro, repito, a multimídia digital interativa pode potencializar consideravelmente as operações realizadas na sua ausência. Em comparação, a sala de aula inforrica pode ter computadores ligados à Internet e oferecer a cada aluno um endereço eletrônico pessoal, mas não será interativa enquanto prevalecer a "pedagogia da transmissão" ou mesmo o professor "parceiro", o "conselheiro", o "facilitador". Isso sem falar dos softwares "educativos" concebidos para potenciar a aprendizagem e o trabalho do professor, mas que possuem metodologias fechadas, não permitindo a participação direta do professor e dos alunos. Softwares que contêm aulas prontas (pacotes), sem possibilidade de personalização, de modificação de seus conteúdos porque são estáticos, fixos, com links arborescentes, limitados - aliás, são os que mais existem no mercado. Pode-se concluir então que o que está em evidência é a imbricação de uma nova modalidade de comunicação e uma nova modalidade de aprendizagem na sala de aula presencial infopobre e inforrica e na educação on-line. Algo que podemos chamar de sala de aula interativa.

Sintonizado com a cibercultura e com a interatividade, o professor percebe que o conhecimento não está mais centrado no seu falar-ditar. Percebe que os atores da comunicação têm a interatividade e não a separação da emissão e recepção própria da mídia de massa e da cultura da escrita, quando autor e leitor não estão em interação direta. Ele propõe o conhecimento atento a certos cuidados essenciais junto da interlocução, e assim, redimensiona a sua autoria. Substitui a prevalência do falar-ditar, da distribuição, pela perspectiva da proposição complexa do conhecimento, da participação ativa dos aprendizes que já aprenderam com o videogame e hoje aprendem com 0 mouse. Enfim, não foge à responsabilidade de disseminar um outro modo de pensamento, de inventar uma nova sala de aula, presencial e a distância (online), capaz de educar, de promover educação cidadã na cibercultura.

Assim, juntamente com a valiosa orientação dos nossos clássicos mestres da educação, temos agora um novo paradigma comunicacional em emergência na cibercultura. Juntamente com os apelos da "escola democrática" e da "pedagogia do oprimido", temos agora possibilidades de materialização de uma atitude comunicacional que não apenas atenta idealmente para a participação e para a dialógica, mas que também as promove concretamente no cotidiano da sala de aula presencial e a distância. 


\section{Referências}

ALAVA, Serafin. Ciberespaço e formações abertas: rumo a novas práticas educacionais. Tradução de Fátima Murad. Porto Alegre: Artmed, 2002.

FREIRE, Paulo. Pedagogia do oprimido. 6. ed . Rio de Janeiro,RJ: Paz e Terra, 1978.

. Pedagogia da esperança. Rio de Janeiro,RJ: Paz e Terra, 1992.

. Educação e mudança. Rio de Janeiro,RJ: Paz e Terra, 1979.

A importância do ato de ler. São Paulo,SP: Autores Associados/ Cortez, 1982.

JOHNSON, Steven. Cultura da interface: como o computador transforma nossa maneira de criar e comunicar. Tradução de Maria Luiza Borges. Rio de Janeiro, RJ: Zahar, 2001.

KUMAR, Krishan. Da sociedade pós-industrial à pós-moderna: novas teorias sobre o mundo contemporâneo. Tradução de Ruy Jungmann. Rio de Janeiro,RJ: Zahar, 1997.

LANDOW, George P. Hypertext: the convergence of contemporary critical theory and technology. Baltimore: Johns Hopkins, 1992.

LÉVY, Pierre. Cibercultura. Tradução de Carlos Irineu da Costa. São Paulo,SP: Editora, 34, 1999.

MACHADO , Arlindo. Pré-cinemas \& pós-cinemas. Campinas: Papirus, 1997.

. Audiovisual. Folha de São Paulo, São Paulo, 13 abr.1997.

Máquina e imaginário: o desafio das poéticas tecnológicas. São Paulo,SP: Edusp, 1993.

MARCHAND, Marie. Les paradis informationnels - du Minitel aux services de commmunication du futur. Paris: Masson, 1987.

MARTÍN-BARBERO, Jesús. Nuevos regímenes de visualidad y descentramientos culturales. Bogota (Colômbia), 1998. Cópia reprográfica.

PALLOFF, Rena M. ; PRATT, Keith. Construindo comunidades de aprendizagem no ciberespaço: estratégias eficientes para salas de aula on-line. Tradução de Vinicius Figueira. Porto Alegre: Artimed, 2002.

PASSARELL, Brasilina. Hipermídia e a educação: algumas perspectivas e experiências. Contex to e Educação, Ijuí, 34, p. 62-80, 1993. 
. Hipermídia na aprendizagem: construção de um protótipo interativo: a escravidão no Brasil. Tecnologia Educacional, Rio de Janeiro, v. 22, n.113/ 114, p. 35-38, jul./out. 1993.

SFEZ, Lucien. Crítica da comunicação. Trad. Maria Stela Gonçalves et ali. São Paulo,SP: Loyola 1994.

SILVA, Marco. Sala de aula interativa. Rio de Janeiro,RJ: Quartet, 2000.

. (Org.). Educação on-line. São Paulo,SP: Loyola: 2003.

De Anísio Teixeira à Cibercultura: desafio para a formação de professores ontem, hoje e amanhã. In: Boletim Técnico do Senac, Rio de Janeiro, v.29, n.3, p. 31-41, set./dez., 2003,.

SANTOS, Edméa Oliveira dos. Articulação de saberes na EAD on-line: por uma rede interdisciplinar e interativa de conhecimentos em ambientes virtuais de aprendizagem. In: M. SILVA (org). Educação on-line. São Paulo: Loyola, 2003. p. 217-230.

- O currículo em rede e o ciberespaço como desafio para a EAD. In: ALVES, Lynn; NOVA, Cristiane (orgs). Educação a distância. Uma nova concepção de aprendizado e interatividade. São Paulo,SP: Futura, 2003. p, 136-148.

TAPSCOTT, Don. Geração digital: a crescente e irredutível ascensão da geração net. Trad. Ruth Bahr. São Paulo: MAKRON Books, 1999.

TEIXEIRA, Anísio. Mestres de amanhã . Disponível em http:// www.prossiga.br/ anisioteixeira/artigos/mestres.html Acesso em: 20 fev. 2003. 